\title{
AKRUAL
}

Jurnal Akuntansi

http://fe.unesa.ac.id/ojs/index.php/akrl

\section{KONTRIBUSI PRIVATE INVESTMENT DAN BELANJA MODAL PEMERINTAH TERHADAP NILAI TAMBAH EKONOMI DAN PENYERAPAN TENAGA KERJA KAB/KOTA HIGHT ECONOMIC DI PROVINSI JAWA TIMUR} (KOTA SURABAYA, KOTA KEDIRI, KAB.SIDOARJO, KAB.GRESIK)

\author{
Didin Fatihudin \\ Fakultas Ekonomi Universitas Muhammadiyah Surabaya \\ e-mail: dfatihudin@yahoo.co.id
}

Artikel diterima: 20 Mei 2012

Terakhir direvisi: 30 Juni 2012

\begin{abstract}
The accumulation of capital in one of the determinants of economic growth factors in addition to the economic potential and population. Private investment and government capital expenditure is the implementation of capital accumulation then spent again to enlarge the production capacity and increase asset value. This study gives an overview of how the contribution of private investment and government capital expenditure of district/city economic hight on economic value added and employment in the province of East Java. District/city Surabaya, Kediri, Sidoarjo and Gresik selected from 38 districts/cities in East Java Province. The method of research used samples expost Pacto and purposive sampling techniques. Data obtained from the Central Bureau of Statistics, the Investment Coordinating Board and the Finance Bureau of East Java Governor's Office for five years from 2002 to 2006. Data processing is done manually assisted with Excel and SPSS software program. The results showed that the change in private investment and government capital spending districts / cities have contributed to the change in economic value added and the employment I town in East Java. Private investment and government capital expenditure is very important to increase economic activities in the region. Economic growth districts I cities that use capital-intensive approach (capital intensive) will not be able to absorb labor and expansion of new jobs as experienced Kediri, unless economic growth with labor-intensive approaches (labor intensive).
\end{abstract}

Keywords: Private Investment, Capital Expenditures, Economic Value Added, Labor.

\section{PENDAHULUAN}

Globalisasi ekonomi telah mengindikasikan tidak adanya batas ruang, wilayah dan waktu antara satu negara dengan negara lainnya di dunia. Suatu negara tidak bisa menolak atau menutup diri dari globalisasi pasar dalam sistem perekonomiannya, termasuk Indonesia. Di samping kekurangannya, globalisasi memiliki sejumlah manfaat, yakni terbukanya peluang perdagangan internasional, 
meningkatkan akses pasar dan teknologi, kesehatan yang lebih baik, tumbuhnya demokrasi dan keadilan sosial bagi masyarakat sipil. Kekurangan globalisasi, masalahnya bukan pada globalisasi itu sendiri, tetapi bagaimana globalisasi itu dikelola (Stiglitz,2003:299). Mobilitas barang dan jasa, modal, teknologi serta tenaga kerja, bahkan budaya sekalipun, akan merambah masuk ke berbagai negara. Teknologi informasi, komunikasi dan transportasi semakin maju pesat. Kemajuan ini didorong oleh negara-negara maju yang mampu menginvestasikan kembali modalnya ke dalam produk-produk baru dan inovatif, sehingga pertumbuhan ekonominya cukup tinggi. Kondisi seperti itu menjadi tantangan sekaligus peluang bagi pertumbuhan ekonomi Indonesia ke depan.

Pertumbuhan ekonomi (economic growth) dalam suatu negara ditandai dengan semakin meningkatnya kapasitas barang (goods) dan jasa (services) dalam kurun waktu tertentu (Sen dalam Pressman,2000:274). Pertumbuhan ekonomi dapat dampak positif bagi pendapatan nasional, pada gilirannya juga dapat meningkatkan pendapatan per kapita penduduk dan kesejahteraan masyarakat. Pertumbuhan ekonomi bergantung banyak hal seperti potensi ekonomi negara yang bersangkutan, sumberdaya alam, kuantitas dan kualitas sumberdaya manusia, seberapa besar modal yang dimiliki, seberapa tinggi inovasi teknologi yang dapat dikembangkan untuk menciptakan efisiensi produksi. Dari sisi lain pertumbuhan ekonomi itu juga dipengaruhi oleh kenaikan tingkat konsumsi, investasi, pengeluaran pemerintah dan ekspor netto (Dumairy,1996:136). Untuk mencapai kesejahteraan penduduk itu tidak cukup hanya dipenuhi oleh pertumbuhan barang dan jasa saja, termasuk Indonesia. Perlu pemenuhan lain seperti taraf pendidikan (education), pemenuhan kesehatan (healt) yang diukur dengan usia harapan hidup, dan meningkatnya pendapatan per kapita (income) yang diukur dengan kemampuan daya beli masyarakat.

Untuk menciptakan pertumbuhan dan pembangunan ekonomi, Indonesia termasuk Provinsi Jawa Timur diperlukan memiliki modal (capital) yang besar untuk investasi. Peningkatan modal itu dapat dilakukan, pertama, mencoba mengoptimalkan sumberdaya potensi ekonomi yang dimiliki terlebih dahulu lalu di arahkan pada investasi yang lebih menguntungkan secara finansial. Kedua, kalau modal tersebut masih kurang atau tidak ada sama sekali dengan terpaksa meminjamnya dari pihak lain. Itu suatu hal yang wajar dalam perekonomian, yang penting bagaimana cara mengelola pinjaman itu dengan baik dan efisien. Pokok pinjaman dan suku bunga dapat terbayar tepat waktu, dapat mendatangkan keuntungan (profit) secara ekonomi-sosial dalam jangka panjang. Sebelum melakukan investasi, baik pemerintah pusat/daerah maupun investor swasta harus mampu memikirkan terlebih dahulu; investasi apa yang dapat dikembangkan, siapa saja yang akan melakukan, bagaimana caranya, kapan waktunya yang tepat dilaksanakan, di mana lokasinya dan yang lebih penting adalah dari mana dan seberapa besar modal (capital) yang diperlukan untuk investasi tersebut.

Dalam hal ini peran pemerintah dan swasta sangat penting dalam pembangunan ekonomi. Pembangunan ekonomi Jawa Timur merupakan bagian dari pembangunan ekonomi nasional. Jawa Timur melalui otonomi daerah harus mampu mengatur sumberdaya yang ada, memberi kesempatan peningkatan partisipasi masyarakat serta jaminan keamanan di daerahnya demi peningkatan pertumbuhan ekonomi dan pencapaian kesejahteraan masyarakat. Jawa Timur yang memiliki $38 \mathrm{kab} /$ kota memiliki geografis, potensi ekonomi yang berbeda- 
beda. Potensi ekonomi dan geografis Jawa Timur memiliki peluang besar untuk berkembang lebih maju bila dibandingkan dengan kab/kota provinsi lain. Oleh karena itu menarik untuk di kaji lebih mendalam tentang bagaimana kontribusi private investment dan belanja modal pemerintah terhadap nilai tambah ekonomi dan penyerapan tenaga kerja di kab/kota hight economic se Jawa Timur.

\section{KAJIAN PUSTAKA}

Ada tiga faktor utama dalam pertumbuhan ekonomi yakni; pertama, akumulasi modal; kedua, pertumbuhan penduduk, dan ketiga, kemajuan teknologi. (Todaro, 1999). Akumulasi modal (capital accumulation) meliputi semua jenis investasi baru yang ditanamkan pada tanah, peralatan fisik, dan modal sumberdaya. Akumulasi modal akan terjadi apabila sebagian dari pendapatan ditabungkan (diinvestasikan) kembali dengan tujuan untuk memperbesar output atau pendapatan dikemudian hari. Menurut Smith secara sistematis ada dua aspek utama Pertumbuhan ekonomi jangka panjang: pertama, pertumbuhan output (GDP) total, kedua, pertumbuhan penduduk. Dalam pertumbuhan output menyatakan bahwa sistem produksi suatu negara terdiri dari tiga unsur pokok; (a) sumber daya alam (b) sumber daya manusia (jumlah penduduk), dan (c) stock barang kapital yang ada (Budiono,1999). Pertumbuhan ekonomi menaikan pendapatan per kapita, sementara perkembangan ekonomi meningkatkan harapan hidup, bebas buta huruf, kesehatan dan pendidikan masyarakat (Sen dalam Pressman, 2000).

Investasi (invesment) dalam teori ekonomi berarti kegiatan perbelanjaan untuk meningkatkan kapasitas memproduksi sesuatu perekonomian. Pengeluaran untuk mendirikan pabrik, membeli mesin-mesin produksi, penyediaan bahan mentah atau memperluas perkebunan sehingga mendatangkan keuntungan dimasa datang (Sukirno,2000). Investasi diartikan sebagai pengeluaran-pengeluaran atau penanaman modal bagi perusahaan untuk membeli barang modal dan perlengkapan produksi untuk menambah kemampuan produksi barang dan jasa dalam perekonomian. Pertambahan jumlah barang modal memungkinkan perekonomian tersebut menghasilkan lebih banyak barang dan jasa di masa yang akan datang. Faktor-faktor utama yang menentukan tingkat investasi adalah suku bunga, prediksi tingkat keuntungan, prediksi mengenai kondisi ekonomi ke depan, kemajuan teknologi, tingkat pendapatan nasional, dan keuntungan perusahaan.

Menurut Robinson (Rosyidi,2004) investasi (investment) dalam teori ekonomi diartikan sebagai penanaman modal, penambahan barang-barang modal baru (new capital formation). Pengeluaran investasi menurut penggunaannya dibagi menjadi tiga kepentingan yaitu; pertama, konstruksi (construction); kedua, perbaikan (rehabilization), dan ketiga, perluasan (expansion). Konstruksi adalah pengeluaran untuk membangun sesuatu hal yang memang baru ; rehabilitasi pengeluaran yang diperuntukkan memperbaiki sesuatu yang sudah rusak (menyusut). Sedangkan ekspansi yaitu pengeluaran untuk memperbesar kapasitas, mempertinggi volume atau memperlebar ruang gerak investasi itu terdiri dari dua macam, yakni investasi bruto dan investasi neto. investasi bruto adalah investasi total yang terjadi di dalam sistem ekonomi. Investasi ini dibagi menjadi dua bagian ; (1) investasi penggantian dan (2)investasi neto. Investasi penggantian adalah jumlah investasi yang sekadar mempertahankan sediaan modal yang ada, (disebut dengan cadangan konsumsi modal/penyusutan). Investasi bruto dikurangi 
dengan investasi penggantian sama dengan investasi neto. Investasi neto yang positif akan menaikkan sediaan modal total sistem ekonomi, sedangkan (2) investasi penggantian mempertahankan sediaan modal yang ada dengan menggantikan apa yang sudah habis digunakan. Semua investasi bruto dimasukan ke dalam perhitungan pendapatan nasional. Hal ini disebabkan karena semua investasi barang merupakan bagian dari keluaran total nasional dan produksinya menghasilkan pendapatan dan kesempatan kerja apakah barang yang diproduksi itu merupakan bagian dari investasi neto ataukah hanya merupakan investasi penggantian (Lipsey et al. Paul N.Courant, Douglas D Purvis, Peter O Steiner, 1995).

Menurut Keynes (Rosyidi, 2004) keputusan untuk membeli barang modal (investasi riil) menyatakan bahwa investasi tergantung dari tingkat bunga yang dibandingkan dengan MEC (marginal efficiency of capital) yang menunjukkan keuntungan pembelian suatu barang modal. Tingkat bunga menunjukkan biaya modal yang dipinjam, atau menunjukkan biaya oportunitas bagi pemilik modal. Adapun kriteria pengambilan keputusan dilaksanakan atau tidaknya suatu jenis investasi riil dapat berpatokan pada kriteria di bawah ini; (a) Apabila $r>\mathrm{i}$; proyek investasi tersebut layak dilaksanakan karena menguntungkan : (b) Apabila $r=i$; proyek investasi boleh dilaksanakan atau tidak, tergantung prospek di masa mendatang dari investasi tersebut: (c) Apabila $\mathrm{r}<\mathrm{i}$; investasi tidak layak untuk dilaksanakan karena merugi. Di mana $r$ atau disebut MEC (marginal efficiency of capital) adalah keuntungan (revenue) yang diperoleh selama periode investasi dilaksanakan, sedangkan i adalah suku bunga (interest).

Hasil penelitian Fatihudin (2011) menunjukkan: Investasi swasta berpengaruh secara positif dan signifikan terhadap pertumbuhan ekonomi. Investasi swasta berpengaruh secara positif dan signifikan terhadap penyerapan tenaga kerja. Investasi pemerintah berpengaruh secara positif dan signifikan terhadap pertumbuhan ekonomi.Investasi pemerintah tidak berpengaruh dan non signifikan terhadap penyerapan tenaga kerja. Pertumbuhan ekonomi berpengaruh secara positif dan signifikan terhadap penyerapan tenaga kerja. Pertumbuhan ekonomi berpengaruh secara positif dan signifikan terhadap kesejahteraan masyarakat. Penyerapan tenaga kerja berpengaruh secara negatif dan signifikan terhadap kesejahteraan masyarakat. Fuadi (2003)Untuk menarik investasi harus dimulai memahami preferensi investor terhadap daya tarik investasi. Hasil penelitiannya menunjukkan bahwa faktor-faktor yang mempengaruhi daya tarik investasi adalah; ketersediaan bahan baku, produktivitas tenaga kerja tinggi;jaminan keamanan, kepastian birokrasi, tersedianya jaringan transportasi yang baik. Sosial budaya masyarakat motivasi kerja, distribusi kekayaan, budaya wirausaha.

\section{METODE PENELITIAN}

Metode yang dipakai dalam penelitian ini ex post facto. Teknik sampelnya purposive sampling. Obyek penelitian yang dipilih 4 (empat) kab/kota dari 38 kab/kota se Provinsi Jawa Timur, yakni Kota Surabaya, Kota Kediri, Kab.Sidoarjo dan Kab.Gresik. Kategori kab/kota hight economic tersebut mengacu pada klasifikasi UNDP-World Bank yang indikator dan ukurannya diturunkan disesuaikan dengan kondisi Kab/kota di Jawa Timur. Data yang dikumpulkan data sekunder tentang realisasi private investment (domestik dan 
asing), belanja modal pemerintah dari APBD, penyerapan tenaga kerja dan nilai tambah ekonomi dari keempat kab/kota tersebut selama lima tahun 2002 hingga 2006. Pengolahan datanya dilakukan secara manual dibantu dengan program software Excel dan SPSS.

\section{HASIL DAN PEMBAHASAN}

Pertumbuhan dan pembangunan ekonomi sangat dipengaruhi oleh banyak faktoir antara lain adalah potensi sumber daya alam, tenaga kerja dan akumulasi modal. Akumulasi modal berasal dari investasi swasta dan investasi pemerintah. Private investment adalah belanja modal yang dikeluarkan oleh sektor swasta dengan tujuan untuk memperbesar kapasitas produksi dan memaksimumkan keuntungan (profit) sektor swasta. Investasi pemerintah adalah belanja modal pemerintah dikeluarkan melalui APBD yang memiliki nilai ekonomi dan sosial (public). Hasil penelitian ini untuk menunjukkan arah (trend) realisasi private invesment, belanja pemerintah, penyerapan tenaga kerja dan nilai tambah ekonomi dari keempat kab/kota yang termasuk Hight economic se Provinsi Jawa Timur, yakni Kota Surabaya, Kota Kediri, Kab.Sidoarjo dan Kab.Gresik dalam kurun waktu tahun 2002 hingga tahun 2006. Untuk lebih jelasnya dapat dilihat pada tabel-tabel berikut ini:

1. Private Investment

Berdasarkan tabel di bawah menunjukkan bahwa realisasi private investment ini meliputi investasi domestik dan asing kab/kota hight economic di Jawa Timur. Secara keseluruhan nilai investasi tersebut yang paling tinggi ditempati oleh Kota Surabaya. Nilai realisasi paling rendah adalah Kab.Sidoarjo. Kota Kediri urutan kedua dan Gresik urutan ketiga. Realisasi investasi swasta domestik di Kota Surabaya trendnya meningkat terus dari 2002 hingga 2005 dari nilai 118.980,00 hingga nilai $3.367 .142,00$ milyar rupiah, kecuali pada tahun 2006 mengalami penurunan nilai realisasinya hanya 623.330,00 milyar rupiah saja. Nilai realisasi investasi domestik tertinggi hanya pada tahun 2005 yakni sebesar 3.367.142,00 milyar rupiah. Sedangkan nilai realisasi investasi asing di Surabaya arahnya naik-turun dan kenaikkan juga kurang signifikan, misalnya dari tahun 2002 ke 2003 mengalami kenaikan, tetapi hanya dari nilai realisasi sebesar 10.418,00 \$US menjadi sebesar 93.163,00 \$US. Dari 2003 ke 2004 mengalami penurunan yakni dari nilai sebesar 93.163,00 \$US menjadi 81.765,00 \$US, tetapi dari 2004 ke 2005 nilainya kembali meningkat dari sebesar 81.765,00 \$US menjadi sebesar 92.997,00 \$US dan turun kembali tahun 2006 menjadi sebesar 47.963,00 \$US.

Tabel 1. Nilai Realisasi Private Investment (Domestik) Empat Kab/Kota High Economic di Jawa Timur 2002 S.D 2006 (Juta Rupiah)

\begin{tabular}{lrrrrr}
\hline $\begin{array}{l}\text { Kab/Kota } \\
\text { H.E. }\end{array}$ & \multicolumn{1}{c}{ DN'02 } & \multicolumn{1}{c}{ DN'03 } & \multicolumn{1}{c}{ DN'04 } & \multicolumn{1}{c}{ DN'05 } & \multicolumn{1}{c}{ DN'06 } \\
\hline Surabaya & $118.980,00$ & $200.853,00$ & $261.555,00$ & $3.367 .142,00$ & $623.330,00$ \\
Kediri & $123.121,00$ & $154.517,00$ & $356.557,00$ & $29.212,00$ & $21.600,00$ \\
Sidoarjo & 0,00 & $354.233,00$ & $693.114,00$ & $520.033,00$ & $369.174,00$ \\
Gresik & 0,00 & $243.350,00$ & $721.761,00$ & $555.247,00$ & $1.974 .589,00$ \\
Jawa & $1.025 .893,00$ & $1.436 .312,00$ & $5.473 .860,00$ & $5.400 .966,00$ & $167.413 .272,00$ \\
Timur & & & & &
\end{tabular}

Sumber: BKPM Jakarta dan BPS-JATIM, diolah 
Tabel 2. Nilai Realisasi Private Investment (Asing) Empat Kab/Kota High Economic di Jawa Timur 2002 s.d 2006 (\$Us)

\begin{tabular}{lrrrrr}
\hline $\begin{array}{l}\text { Kab/Kota } \\
\text { H.E. }\end{array}$ & \multicolumn{1}{c}{ AS'02 } & \multicolumn{1}{c}{ AS'03 } & \multicolumn{1}{c}{ AS'04 } & \multicolumn{1}{c}{ AS'05 } & \multicolumn{1}{c}{ AS'06 } \\
\hline Surabaya & $10.418,00$ & $93.163,00$ & $81.765,00$ & $92.997,00$ & $47.963,00$ \\
Kediri & $8.523,00$ & $3.770,00$ & 645,00 & $8.233,00$ & 788,00 \\
Sidoarjo & $4.205,00$ & $26.024,00$ & $24.757,00$ & $93.390,00$ & $493.424,00$ \\
Gresik & $29.070,00$ & $58.656,00$ & $41.474,00$ & $192.695,00$ & $66.240,00$ \\
Jawa & $113.579,00$ & $456.677,00$ & $357.761,00$ & $544.028,00$ & $1.467 .649,00$ \\
Timur & & & & & \\
\hline
\end{tabular}

Sumber : BKPM Jakarta dan BPS-JATIM, diolah

Tabel 3. Trend Private Invesment Domestik dan Asing

\begin{tabular}{lrrrrrrrr}
\hline $\begin{array}{l}\text { Kab/Kota } \\
\text { H.E. }\end{array}$ & DN'03 & AS'03 & DN'04 & AS'04 & DN'05 & AS,05 & DN,06 & AS'06 \\
\hline Surabaya & 68.81 & 794.25 & 30.22 & $(12.23)$ & $1,187.36$ & 13.74 & $(81.49)$ & $(48.43)$ \\
Kediri & 25.50 & $(55.77)$ & 130.76 & $(82.89)$ & $(91.81)$ & $1,176.43$ & $(26.06)$ & $(90.43)$ \\
Sidoarjo & 0 & 518.88 & 95.67 & $(4.87)$ & $(24.97)$ & 277.23 & $(29.01)$ & 428.35 \\
Gresik & 0 & 102.50 & 196.59 & $(29.55)$ & $(23.07)$ & 364.62 & 255.62 & $(65.62)$ \\
Jawa & 40.01 & 302.08 & 281.11 & $(21.66)$ & $(1.33)$ & 52.06 & $2,999.69$ & 169.77 \\
Timur & & & & & & &
\end{tabular}

Sumber : BKPM Jakarta dan BPS-JATIM, diolah

Adapun Kota Kediri trend realisasi private investment; investasi domestik dari tahun 2002 hingga 2004 mengalami kenaikan terus yakni dari 123.121,00 milyar rupiah menjadi $154.517,00$ menjadi $356.557,00$ milyar rupiah, tetapi dari tahun 2005 ke tahun 2006 mengalami penurunan drastis dari sebesar 29.212,00 milyar rupiah menjadi 21.600,00 milyar rupiah. Sedangkan investasi asing mengalami penurunan dari 2002 hingga 2004 sebesar 8.523,00 menjadi sebesar 645,00 \$US, tetapi mulai tahun 2005 naik kembali sebesar 8.233,00 \$US, tetapi berikutnya 2006 menurun kembali nilainya menjadi 788,00 \$US. Trend realisasi private investment (domestik) Kab.Sidoarjo untuk 2002 tidak ada nilai realisasi investasi, tetapi mulai 2003 hingga 2005 mengalami peningkatan yakni sebesar 354.233,00 milyar rupiah menjadi sebesar 693.114,00 dan 520.033,00 milyar rupiah, tetapi 2006 kembali turun menjadi sebesar 369.174,00 milyar rupiah. Sedangkan nilai realisasi investasi asing di Kab.Sidoarjo secara keseluruhan dari mulai tahun 2002 hingga tahun 2006 mengalami kenaikan yang terus menerus dari mulai nilai sebesar 4.205,00 \$US hingga nilai sebesar 493.424,00 \$US. Adapun Trend realisasi private investment Kab.Gresik untuk domestik relatif meningkat terus mulai tahun 2003 hingga 2006 yakni sebesar 243.350,00 hingga sebesar 1.974.589,00 milyar rupiah, tetapi pada tahun 2002 tidak ada. Investasi asing nilai realisasinya mengalami fluktuasi yakni dari tahun 2002 ke 2003 sebesar 29.070,00 menjadi sebesar 58.656,00 \$US, dari tahun 2003 ke 2004 mengalami penurunan sebesar 41.474,00 \$US, tetapi dari 2004 ke 2005 meningkat lagi sebesar 192.695,00 \$US kemudian menurun kembali sebesar 66.240,00 \$US. 
2. Belanja Modal Pemerintah

Tabel 4. Realisasi Belanja Modal Pemerintah Empat Kabupaten/Kota High Economic Di Jawa Timur 2002 s.d 2006 (Jutaan Rupiah)

\begin{tabular}{lrrrrr}
\hline Kab/Kota & \multicolumn{1}{c}{$\mathbf{0 2}$} & \multicolumn{1}{c}{$\mathbf{0 3}$} & \multicolumn{1}{c}{$\mathbf{0 4}$} & $\mathbf{6 5}$ & $\mathbf{6}$ \\
H.E & $247.917 .303 .980,00$ & $37.608 .192 .488 .810,00$ & $177.506 .829 .652,00$ & $206.159 .771 .550,00$ & $143.867 .223 .157,00$ \\
\hline Surabaya & $61.364 .556 .001,00$ & $63.650 .826 .950,00$ & $40.681 .419 .800,00$ & $2.818 .026 .965 .753,00$ & $67.704 .871 .372,00$ \\
Kediri & $122.375 .811 .822,00$ & $111.779 .174 .653,00$ & $87.550 .924 .220,00$ & $156.208 .345 .334,00$ & $265.743 .163 .076,00$ \\
Sidoarjo & $109.526 .581 .751,00$ & $80.524 .076 .011,00$ & $4.548 .918 .126 .955,00$ & $47.399 .932 .776,00$ & $112.833 .883 .382,00$ \\
Gresik & & & & \\
Jawa & $43.532 .464 .076 .453,20$ & $160.696 .084 .908 .807,00$ & $46.771 .067 .202 .221,00$ & $26.885 .897 .464 .984,00$ \\
Timur & & & & $69.340 .043 .863 .972,00$ \\
\hline
\end{tabular}

Tabel 5. Trend Belanja Modal Pemerintah 2002-2006

\begin{tabular}{lrrrr}
\hline Kab/Kota H.E & $\mathbf{6 0 3}$ & $\boldsymbol{'} \mathbf{0 4}$ & $\boldsymbol{'} \mathbf{0 5}$ & $\mathbf{6}$ \\
\hline Surabaya & $15,069.65$ & -99.53 & 16.14 & -30.22 \\
Kediri & 3.73 & -36.09 & 6827.06 & -97.60 \\
Sidoarjo & $(8.66)$ & -21.68 & 78.42 & 70.12 \\
Gresik & $(26.48)$ & 5549.14 & -98.96 & 138.05 \\
Jawa Timur & 269.14 & -70.89 & -42.52 & 157.90 \\
\hline
\end{tabular}

Sumber : Biro Keuangan Kantor Gubernur Provinsi Jawa Timur diolah

Belanja modal pemerintah empat kabupaten/kota hight economic Surabaya, Kediri, Sidoarjo dan Gresik di Provinsi Jawa Timur berdasarkan tabel di atas menunjukkan bahwa realisasi belanja modal Kota Surabaya selama lima tahun mengalami fluktuasi yakni meningkat dari tahun 2002 ke 2003 sebesar 15,069.65 milyar rupiah, dari tahun 2004 ke tahun 2005 sebesar 16.14 milyar rupiah. Realisasi belanja modal Kota Surabaya mengalami penurunan dari tahun 2003 ke tahun 2004 sebesar -99.53 milyar rupiah dan dari tahun 2005 ke tahun 2005 sebesar -30.22 milyar rupiah.

Realisasi belanja modal Kota Kediri juga mengalami fluktuasi dari tahun ke tahun meningkat sebesar 3.73 milyar rupiah dari tahun 2002 ke tahun 2003 dan sebesar 6827.06 milyar rupiah dari tahun 2004 ke tahun 2005. Mengalami penurunan realisasi belanja modal Kota Kediri, yakni dari tahun 2003 ke tahun 2004 sebesar -36.09 milyar rupiah dan dari tahun 2005 ke tahun 206 sebesar 97.60 milyar rupiah. Agak sedikit berbeda dengan realisasi belanja modal Kab.Sidoarjo meningkat dan menurunnya periode tahunnya hampir berurutan seperti mengalami penurunan mulai dari tahun 2002 hingga tahun 2004 masing-masing sebesar (8.66) milyar rupiah dan sebesar -21.68 milyar rupiah. Realisasi belanja modal Kab.Sidoarjo mengalami peningkatan yakni dari tahun 2004 ke tahun 2005 dan dari tahun 2005 ke tahun 2006 masing-masing nilai realisasinya sebesar 78.42 milyar rupiah dan sebesar 70.12 milyar rupiah.

Adapun realisasi belanja modal Kab.Gresik juga mengalami fluktuasi dari tahun ke tahun mengalami penurunan dari tahun 2002 ke tahun 2003 sebesar (26.48) milyar rupiah dan dari tahun 2004 ke tahun 2005 sebesar -98.96 milyar rupiah. mengalami peningkatan kembali dari tahun 2003 ke tahun 2004 sebesar 5549.14 milyar rupiah dan dari tahun 2005 ke tahun 2006 sebesar 138.05 
milyar rupiah. Berbeda dengan realisasi belanja modal Jawa Timur justru yang menurun realisasinya adalah pada tahun 2003 ke tahun 2004 sebesar -70.89 milyar rupiah dan dari tahun 2004 ke tahun 2005 sebesar -42.52 milyar rupiah, sedangkan yang meningkat realisasi belanja modal Jawa Timur adalah dari tahun 2002 ke tahun 2003 sebesar 269.14 milyar rupiah dan dari tahun 2005 ke tahun 2006 sebesar 157.90 milyar rupiah. Kalau dibandingkan antara realisasi belanja modal kab/kota Surabaya, Kediri, Sidoarjo, Gresik dengan realisasi belanja modal provinsi Jawa Timur berfluktuasi hampir sama, tetapi pada umumnya mengalami penurunan realisasi belanja pemerintah pada tahun 2004, kecuali kabupaten Gresik justru pada tahun 2004 meningkat sebesar 5549.14 milyar rupiah.

3. Nilai Tambah Ekonomi

Tabel 6. Nilai Tambah Ekonomi Harga Konstan 2000 Empat Kabupaten/Kota Hight Economic Di Jawa Timur 2002 s.d . 2006 (Jutaan Rupiah)

\begin{tabular}{|c|c|c|c|c|c|}
\hline $\begin{array}{l}\text { Kab/Kota } \\
\text { H.E }\end{array}$ & '02 & '03 & '04 & '05 & '06 \\
\hline Surabaya & $56.205 .719,21$ & $59.149 .440,17$ & $63.161 .741,31$ & $67.489 .407,61$ & $71.970 .704,39$ \\
\hline Kediri & $17.393 .269,27$ & $18.053 .884,50$ & $19.017 .421,57$ & $19.521 .703,85$ & $20.231 .419,68$ \\
\hline Sidoarjo & $18.495 .988,26$ & $19.582 .090,33$ & $21.130 .369,91$ & $22.545 .144,04$ & $23.588 .581,91$ \\
\hline Gresik & $10.397 .904,56$ & $10.928 .244,97$ & $11.558 .833,45$ & $12.459 .285,44$ & $13.316 .414,20$ \\
\hline Jawa Timur & $218.452 .389,09$ & $228.884 .458,54$ & $242.228 .892,17$ & $266.374 .708,76$ & $271.237 .674,31$ \\
\hline
\end{tabular}

Tabel 7. Laju Economic Growth (Persen)

\begin{tabular}{lccccc}
\hline Kab/Kota H.E. & $\mathbf{6}$ & $\mathbf{6 2}$ & $\mathbf{0 3}$ & $\mathbf{0 4}$ & $\mathbf{0 5}$ \\
\hline Surabaya & 6,71 & 5,11 & 6,71 & 6,93 & 7,02 \\
Kediri & 7,29 & 5,33 & 7,29 & 0,43 & 0,66 \\
Sidoarjo & 6,14 & 5,35 & 6,14 & 7,48 & 5,94 \\
Gresik & 7,05 & 5,62 & 7,05 & 8,52 & 6,75 \\
Jawa Timur & 4,56 & 4,78 & 5,83 & 5,84 & 5,80 \\
\hline
\end{tabular}

Sumber : BPS Jawa Timur,Kabupaten/Kota, diolah

Bila mengamati tabel laju pertumbuhan ekonomi menunjukkan bahwa empat Kab/Kota Hight Economic Surabaya, Kediri, Sidoarjo,dan Gresik nilianya antara 6 hingga 7 persen pada umumnya berada di atas laju pertumbuhan ekonomi Provinsi Jawa Timur yang hanya sebesar rata-rata tiap tahun hanya 4 hingga 5 persen saja. Surabaya setiap tahun meningkat, kecuali pada tahun 2002 ke tahun 2003 menurun dari sebesar 6,71 persen menjadi sebesar 5,11 persen saja. Kota Kediri lebih parah selama tiga periode mengalami penurunan laju pertumbuhan ekonomi yakni dari tahun 2002 ke tahun 2003 masing-masing sebesar 5,33 persen, dari tahun 2004 ke 2005 sebesar 0,43 persen dan tahun 2005 ke tahun 2006 sebesar 066 persen. Semua kab/kota pada tahun 2003 mengalami penurunan laju pertumbuhan ekonomi. Bila dilihat trend-nya bahwa laju pertumbuhan ekonomi Jawa Timur setiap tahunnya mengalami peningkatan antara 4,7 persen hingga 5,8 persen. 
1. Tabel Penyerapan Tenaga Kerja

Tabel 8. Pertumbuhan Penyerapan Tenaga Kerja Empat Kabupaten/Kota Hight Economic di Jawa Timur 2002 S.D. 2006 (Dalam Persen)

\begin{tabular}{lrrrrr}
\hline Kab/Kota H.E & $\mathbf{0 2}$ & $\mathbf{6 3}$ & $\mathbf{0 4}$ & $\mathbf{0 5}$ & $\mathbf{0 6}$ \\
\hline Surabaya & 21,76 & 8,59 & $-14,22$ & 7,70 & 17,82 \\
Kediri & 19,35 & 0,55 & $-14,07$ & $-0,50$ & 10,79 \\
Sidoarjo & 18,24 & 6,84 & $-14,71$ & 11,33 & $-1,68$ \\
Gresik & 24,64 & 2,61 & $-10,65$ & 1,94 & $-2,14$ \\
Jawa Timur & 20,40 & 9,13 & $-12,61$ & 4,98 & 0,00 \\
\hline
\end{tabular}

Sumber : Data BPS Jawa Timur/Kab.Kota, diolah.

Tabel 9. Elastisitas Penyerapan Tenaga Kerja ( Persen)

\begin{tabular}{lccccc}
\hline Kab/Kota H.E. & '02 & '03 & '04 & '05 & '06 \\
\hline Surabaya & 2,19 & 2,26 & 1,82 & 1,83 & 2,02 \\
Kediri & 0,74 & 0,72 & 0,59 & 0,57 & 0,61 \\
Sidoarjo & 4,24 & 4,28 & 3,38 & 3,53 & 3,32 \\
Gresik & 4,87 & 4,75 & 4,01 & 3,80 & 3,48 \\
Jawa Timur & 8,04 & 8,37 & 6,89 & 6,84 & 6,58 \\
\hline
\end{tabular}

Sumber : Data BPS Jawa Timur/Kab.Kota, diolah.

Bila mengamati tabel pertumbuhan penyerapan tenaga kerja empat kabupaten/kota hight economic di Jawa Timur menunjukkan bahwa khusus pada tahun 2004 seluruh empat kab/kota Surabaya, Kediri, Sidoarjo, Gresik tersebut mengalami penurunan penyerapan tenaga kerja bahkan bisa dinyatakan minus penyerapan tenaga kerja di seluruh kab/kota rata-rata sebesar 14 persen, kecuali Gresik sebesar 10 persen saja. Penurunan tersebut termasuk penyerapan tenaga kerja seluruh kab/kota se Provinsi Jawa Timur yakni sebesar -12,61 persen. Kota Surabaya mengalami penurunan yang terus menerus hampir tiap tahun mulai tahun 2002 hingga tahun 2005 yakni masingmasing sebesar 8,59 persen dari tahun 2003 ke tahun 2004, sebesar $-14,22$ persen dari tahun 2003 ke tahun 2004, sebesar 7,70 persen dari tahun 2004 ke tahun 2005, kecuali pada tahun 2006 mengalami peningkatan sebesar 17,82 persen. Mengalami minus penyerapan tenaga kerja masing-masing kediri tahun 2004 dan tahun 2005, Gresik dan Sidoarjo juga dua tahun yakni tahun 2004 dan tahun 2006. Minus penyerapan yang paling kecil bila dibanding ketiga kab/kota, Gresik paling rendah minusnya antara 2 persen hingga 10 persen saja. Kab.Sidoarjo pada tahun 2006 hanya 1 persen saja.

Berkaitan dengan investasi kab/kota di Jawa Timur menurut Samuelson (2004) ada tiga faktor utama yang mempengaruhi investasi, yakni ; suku bunga sebagai biaya modal yang dipinjam untuk investasi (Cost), ekspektasi bagaimana ekonomi di masa depan (revenue), dan tidak kalah penting adalah kemajuan teknologi (inovasi). Lebih jelas Harrod-Domar (Jhingan,2007) memberikan peranan kunci kepada investasi di dalam proses pertumbuhan 
ekonomi, khususnya mengenai dampak ganda yang dimiliki investasi; pertama, bahwa investasi dapat menciptakan pendapatan atau sebagai dampak permintaan ; kedua, dengan investasi dapat memperbesar kapasitas produksi dalam perekonomian dengan cara meningkatkan stok modal atau sebagai dampak penawaran. Arah secara keseluruhan kab/kota nilai realisasi investasi swasta menurun semua yakni pada tahun 2004 dari investasi asing dan tahun 2005 dari investasi domestik. Pada tahun 2005 meningkat kembali, tetapi tahun 2006 baik investasi asing maupun investasi domestik juga menurun. Secara umum nilai realisasi investasi domestik maupun asing dari keempat kab/kota Hight economic Kota Surabaya, Kota Kediri, Kab.Sidoarjo, Gresik bila dibandingkan dengan nilai investasi di Jawa Timur keempat kab/kota tersebut masih di bawah nilai realisasi private investmentnya Provinsi Jawa Timur.

Salah satu motor pertumbuhan ekonomi kab/kota dan pembangunan nasional adalah akumulasi modal dari investasi swasta dan dari investasi pemerintah. Oleh karena itu investasi swasta tetap penting dan harus terus ditingkatkan demi keberlangsungan pembangunan nasional di masa mendatang khususnya kab/kota di Jawa Timur. Faktor yang mempengaruhi investasi di Surabaya, Kediri, Sidoarjo dan Gresik tidak akan jauh bedanya sebagaimana hasil penelitian KPPOD (2000) bahwa faktor yang pengaruhi investasi di daerah adalah potensi ekonomi, iklim investasi, keamanan, infrastruktur, kesiapan aparatur, perbankan, kepastian hukum, budaya daerah dan kesiapan tenaga kerja yang dibutuhkan oleh para investor di daerah. Bila ini dapat di penuhi oleh keempat kab/kota tersebut, maka dengan sendirinya investasi di daearha tersebut akan meningkat dan pertumbuhan ekonomi dan penyerapan tenaga kerja akan terpenuhi.

Menurut Harrod-Domar bahwa pengeluaran pemerintah akan berdampak positif pada pertumbuhan ekononomi, peranan investasi memiliki dampak positif melalui proses pengganda (multiplier effect) terhadap permintaan agregat dan penawaran agregat melalui peningkatan kapasitas produksi. Dalam jangka panjang investasi yang dilakukan akan menambah stok capital. Setiap penambahan stok capital masyarakat akan meningkatkan kemampuannya untuk menghasilkan ouput. Keadaan ini berarti adanya peningkatan pertumbuhan ekonomi(Tambunan,2001). Belanja modal pemerintah Surabaya, Kediri, Sidoarjo dan Gresik disamping memiliki nilai ekonomi juga memiliki nilai sosial. Belanja untuk sektor publik seperti infrastruktur dalam jangka panjang akan berpengaruh terhadap kegiatan ekonomi masyarakat dengan adanya akses jalan dan saluran distribusi barang dan jasa. Infrastruktur ituy seperti jalan tol, bandara, terminal, jembatan, bendungan, kantor pemerintah, pasar. Pada giliranya belanja modal pemerintah tersebut juga akan meningkatakan pertumbuhan ekonomi dan pembangunan ekonomi kab/kota di Jawa Timur. Menurut Sukirno (2000) ada tiga faktor utama penentu belanja modal pemerintah, yakni ; pajak yang diterima, tujuan ekonomi, dan stabilisasi politik. Jadi dengan demikian besar kecilnya belanja modal pemerintah itu sangat tergantung kepada penerimaan pajak dan retribusi daerah itu sendiri. Potensi ekonomi kekayaan daerah ikut menentukan besaran investasi pemerintah.

Pertumbuhan ekonomi adalah proses kenaikan output per kapita dalam jangka panjang. Suatu proses yang dinamis, bagaimana suatu perekonomian 
berkembang dari waktu ke waktu dari output totalnya (GDP) dan jumlah penduduk. Pertumbuhan harus mampu menjelaskan bagaimana pertumbuhan output di satu sisi dan bagaimana pertumbuhan jumlah penduduknya sisi lain. Kontribusi sumber daya manusia melalui managerial skill dan modal dioptimalkan untuk peningkatan pertumbuhan ekonomi. Menurut Jhingan (2007) bahwa proses pertumbuhan ekonomi dipengaruhi dua faktor ; faktor ekonomi dan non ekonomi. Pertumbuhan ekonomi suatu negara tergantung pada sumberdaya alamnya, sumberdaya manusia, modal, usaha, teknologi dan sebagainya (ekonomi). Pertumbuhan ekonomi itu harus ditunjang oleh perubahan lembaga sosial, kondisi politik, nilai-nilai moral dan sikap budaya suatu bangsa (non ekonomi). Keterbatasan sumber daya alam dan kekhawatiran kelebihan jumlah penduduk menurut Schumpeter merasa optimis bahwa pertumbuhan ekonomi dapat ditingkatkan terus sesuai dengan kemajuan teknologi (Budiono,1999). Motor penggerak pertumbuhan ekonomi adalah inovasi, dan pelakunya adalah para wiraswasta, inovator atau entrepreuner. Kemajuan ekonomi suatu masyarakat hanya bisa diterangkan oleh inovasi dari para entrepreuner. Inovasi teknologi mampu meningkatkan kapasitas produksi secara lebih efisien.

Banyak faktor yang mempengaruhi nilai tambah ekonomi suatu daerah antara lain potensi sumberdaya alam, ketersediaan tenaga kerja, akumulasi modal, teknologi dan inovasi. Keempat daerah Surabaya, Kediri, Sidoarjo, Gresik masing-masing memiliki potensi, keunggulan dan kelemahan yang berbeda-beda. Sesuai pendapat Todaro (1999) bahwa pertumbuhan ekonomi dipengaruhi oleh akumulasi modal, pertumbuhan penduduk dan kemajuan teknologi. Akumulasi modal akan terjadi apabila sebagian dari pendapatan ditabungkan (diinvestasikan) kembali dengan tujuan untuk memperbesar output atau pendapatan dikemudian hari. Disini menunjukkan bahwa investasi swasta dan investasi pemerintah ini sangat penting untuk menunjang kegiatan ekonomi masyarakat. Begitu pula kuantitas dan kualitas tenaga kerjanya termasuk penguasaan teknologi untuk efisiensi produksi. Efisiensi biaya, ekplorasi alam dan optimalisasi nilai tambah ekonomi menjadi tujuan dari pembangunan ekonomi. Bila Surabaya, Kediri, Sidoarjo, Gresik hendak mencapai pertumbuhan ekonomi yang optimal, maka sebaiknya mengikuti arah dari para ahli tersebut di atas.

Akan berbeda hasilnya bila mengamati tabel elastisitas penyerapan tenaga kerja, karena elastisitas merupakan fungsi dari besaran PDRB kab/kota tersebut terhadap rasio tenaga kerja yang mampu diserap dalam lapangan pekerjaan. Kota Kediri yang pertumbuhan ekonominya cukup tinggi tidak mampu menyerap tenaga kerja baru dikarenakan pertumbuhan ekonominya belum mampu menciptakan/memperluas lapangan kerja baru. Bisa jadi pendekatan yang dipakai untuk pertumbuhan ekonomi Kota Kediri adalah capital intensive. Pertumbuhan ekonomi Kab.Gersik dan Kab.Sidoarjo mampu menyerap tenaga kerja sebesar antara 3 persen hingga 4 persen. Lain halnya dengan pertumbuhan ekonomi Kota Surabaya dan Kota Kediri hanya sedikit mampu menyerap tenaga kerja, yakni hanya sebesar antara 1 persen hingga 2 persen, bahkan Kota kediri yang paling parah yakni sebesar 0,5 hingga 0,6 persen saja. Ini bisa diprediksi bahwa potensi alam dan sumberdaya manusia antara Kota dengan Daerah berbeda, sehingga pendekatan pertumbuhan 
ekonominya juga berbeda. Surabaya dan Kediri lebih dekat kepada pendekatan padat modal atau capital intensive, sedangkan Sidoarjo dan Gresik lebih melekat ke pendekatan padat karya atau labor intensive sehingga pertumbuhan ekonominya mampu menyerap tenaga kerja yang lebih banyak. Bila ada peningkatan penyerapan tenaga di Sidoarjo dan Gresik ini menunjukkan bahwa pertumbuhan ekonomi tersebut mampu memberikan kontribusi pada peningkatan pendapatan masyarakat. Tetapi bila yang terjadi sebaliknya mengalami penurunan penyerapan tenaga kerja misalnya pada tahun 2004 mengalami minus, maka yang terjadi capital intensive yakni pendapatan hanya dinikmati oleh segelintir orang saja. Paling penting adalah bagaimana pertumbuhan ekonomi itu mampu meningkatkan pendapatan masyarakat secara keseluruhan maka yang paling tepat adalah pendekatan labor intensive. Memang banyak faktor lain(Fatihudin,2010), di samping tersedianya lapangan kerja yang mempengaruhi penyerapan tenaga kerja misalnya tingkat upah, kuantitas dan kualitas tenaga kerja yang dibutuhkan, komposisi tenaga kerja. Ada tiga hal yang harus kaji bila ingin mengamati penyerapan tenaga kerja secara konprehensif kab/kota di Jawa Timur yakni ; pertumbuhan penyerapan tenaga kerja dari tahun ke tahun ; kedua rata-rata penyerapan tenaga kerja per sektor (primer, sekunder, tersier) ; dan terakhir adalah harus mempelajari elastisitas penyerapan tenaga kerja. Hal itu baru akan diketahui data tenaga kerja yang sesungguhnya.

Dari hasil penelitian ada beberapa temuan yang diperoleh antara lain; pertama, dilihat dari nilai tambah ekonomi dua kota Surabaya, Kediri dan dua kabupaten Gresik dan Sidoarjo ini termasuk hight economic bila di bandingkan dengan kab/kota yang ada se Provinsi Jawa Timur. Kedua, investasi asing sejak tahun 2004 mengalami penurunan dari tahun ke tahun, kecuali hanya tahun 2005. Ketiga, Benar adanya penurunan private investment dan belanja modal pemerintah Surabaya, Kediri, Sidoarjo, Gresik memiliki kontribusi pada penurunan nilai tambah ekonomi dan penyerapan tenaga kerja. Keempat, nilia tambah ekonomi berkontribusi pada penyerapan tenaga kerja apabila labor intensive digunakan sebagai pendekatan, bukan sebaliknya capital intensive. Penelitian ini sederhana dan memiliki keterbatasan dukungan teori dan penelitian empirik, sehingga pembuktian hasil penelitian ini menjadi terbatas pula. Penelitian ini hanya membahas investasi domestik/asing dan investasi pemerintah yang dikaitkan dengan nilai tambah ekonomi dan penyerapan tenaga kerja. Sebenarnya bila ingin mengkaji kontribusi investasi secara konprehensif seharusnya dilengkapi dengan biaya investasi yang disalurkan perbankan sebagai modal kerja di berbagai sektor lain. Perlu penelitian lanjut untuk lebih mendalam analisisnya dengan menggunakan model/teknik analisis lain seperti Path analysis atau lainnya.

\section{SIMPULAN}

Berdasarkan analisis dan pembahasan dari hasil penelitian, maka dapat ditarik kesimpulan :

1. Perubahan penurunan private investment dan belanja modal pemerintah Surabaya, Kediri, Sidoarjo Gresik memiliki kontribusi pula terhadap pengurangan nilai tambah ekonomi dan penurunan penyerapan tenaga kerja di empat kab/kota hight economic Jawa Timur. 
2. Kenaikan PDRB Kota Kediri tidak mampu menciptakan lapangan kerja yang lebih luas. Peningkatan nilai tambah ekonomi tidak selalu memberikan nilai kontribusi pada penyerapan tenaga kerja, bila policy economic growth menggunakan pendekatan capital intensive, kecuali melalui pendekatan labor intensive.

3. Kota Surabaya, Kota Kediri, Kab.Sidoarjo dan Kab.Gresik termasuk empat kab/kota yang termasuk kategori hight economic dibanding kab/kota lainnya se Provinsi Jawa Timur terbukti laju pertumbuhan ekonominya di atas laju pertumbuhan ekonomi Provinsi Jawa Timur.

4. Nilai tambah ekonomi Surabaya, Kediri, Sidoarjo dan Gresik dipengaruhi oleh banyak faktor antara lain yang paling mendasar adalah potensi sumber daya alam, kualitas tenaga kerja, akumulasi modal, ide-ide baru dan teknologi. 


\section{DAFTAR PUSTAKA}

Abipraja, Soedjono, (2002), Perencanaan Pembangunan di Indonesia, Konsep, Model, Kebijaksanaan, Instrument serta Strategi : Surabaya : Airlangga University Press.

Arsyad, Lincoln,(2004), Pengantar Perencanaan dan Pembangunan Ekonomi Daerah, : Yogyakarta : BPFE-Universitas Gajah Mada.

Badan Pusat Statistik, (2004), Statistik Indonesia : Jakarta

----------, (2007), Analisa Penyusunan Kinerja Makro Ekonomi dan Sosial Jawa Timur.

----------, (2007), Keadaan Angkatan Kerja di Provinsi Jawa Timur : Surabaya.

Badan Koordinasi Penanaman Modal (BKPM), Keputusan Kepala BKPM Nomor 57/SK./2004 Tanggal 20 Juli 2004 Tentang Pedoman dan Tatacara Permohonan Penanaman Modal Dalam Negeri (PMDN) dan Penaman Modal Asing (PMA) di Indonesia, BKPM : Jakarta.

Badan Penanaman Modal (BPM) Provinsi Jawa Timur , 2009 : Surabaya.

Budiono,(1999), Teori Pertumbuhan Ekonomi, Edisi Pertama, Cetakan ke Enam: Yogyakarta : BPFE-UGM.

Dornbusch, Rudiger, and Stanley Fisher, (1986), Macroeconomics, Terjemahan, Edisi ketiga : Jakarta : Eralngga.

Dumairy, (1996), Perekonomian Indonesia : Jakarta : Penerbit Erlangga.

Fuadi, Mamik Mochamad, (2003) Analisis Pola Preferensi Investor Terhadap daya tarik Investasi Di Daerah Dalam Era Otonomi Daerah dan Pasar Bebas ; Tesis S2 Industrial Management Engineering, tidak dipublikasikan : Bandung : ITB.

Fatihudin,Didin,(2010), Pengaruh Investasi Swasta dan Investasi Pemerintah Terhadap Pertumbuhan Ekonomi, Penyerapan Tenaga Kerja dan Kesejahteraan Masyarakat Kab/Kota Se Provinsi Jawa Timur, Disertasi Program Pascasarjana Universitas Airlangga Surabaya, Unpublish.

Halim, Abdul, Theresia Damayanti, (2007), Bunga Rampai Manajemen Keuangan Daerah, Pengelolaan Keuangan Daerah, Edisi Kedua, Cetakan pertama : Yogyakarta : UPP STIM-YKPN.

Indonesia-Nertherland Association ; Indonesia, Belanda, Belgia dan Luxemburg(INA)(2008), Kajian Perda dan Iklim Investasi Daerah di Indonesia : Jakarta : Hasil Penelitian INA

Inpres No.3/2006 Kebijakan tentang Iklim Investasi Bagi Para Menteri, Gubernur dan Bupati/Walikota di Seluruh Indonesia : Jakarta : Pemerintah Pusat.

Jhingan, M.L.,(2007), Ekonomi Pembangunan dan Perencanaan, Edisi keenam Belas : Jakarta: PT.Raja Grafindo Persada.

Kantor Gubernur Provinsi Jawa Timur, Biro Keuangan, (2002-2006), Ringkasan Anggaran Pendapatan Belanja Daerah (APBD) Kab/Kota se-Provinsi Jawa Timur.

Kim, Sung Tai, (1997), The Role of Local Public Sectors in Regional Economic Growth in Korea, Asia Economic Journal, 11 : 155-168

Kuncoro, Mudrajat, (2006), Ekonomika Pembangunan, Teori, Masalah, dan Kebijakan, edisi keempat: Yogyakarta : UPP YKPN. 
KPPOD, USAID dan The Asia Foundation, (2007) Survey tentang Daya Tarik Investasi Daerah pada Pelaku Usaha dari 243 Kabupaten/Kota di 15 Provinsi di Indonesia : Jakarta : Hasil Penelitian.

Lipsey, G.Richard,Paul N.Courant,Douglas D Purvis, Peter O Steiner, (1995), Economics, Terjemahan, Edisi Kesepuluh : Jakarta : Binarupa Aksara.

Mahyudi, Ahmad, (2004), Ekonomi Pembangunan dan Analisis Data Empiris : Jakarta : Ghalia Indonesia.

Meier, GM, (1995), Leading Issues in Economic Development, $3^{\text {rd }}$ : New York, Oxford University Press.

Musgrave, Richard. A. and Peggy B Musgrave, (1991), Public Finance in Theory and Practice, Four Edition : New York, McGraw Hill,Inc.

Pass, Christopher and Bryan Lowes, (1977), Dictionary of Economics, Terjemahan, Edisi kedua : Jakarta : Gelora Aksara Pratama.

Pressman, Steven, (2000), Lima Puluh Pemikir Ekonomi Dunia : Jakarta : PT Radja Grafindo.

Rosyidi, H, (2004), Pengantar Teori Ekonomi Pendekatan Kepada Teori Ekonomi Mikro dan Makro, Edisi baru : Jakarta : Rajawali Pers.

Samuelson, Nordhaus,(2004), Macroeconomics, Terjemahan, edisi ketujuh belas : Jakarta : PT Media Global Edukasi.

Sukirno, Sadono,(2000), Makroekonomi Modern ; Perkembangan Pemikiran dari Klasik Hingga Keynesian Baru : Jakarta : Rajawali Pers.

Stiglitz, Joseph E., (2003), Globalization and Its Discontents, Terjemahan; Jakarta : Ina Publikatama.

Tambunan,Tulus, (2001), Perekonomian Indonesia ; Beberapa Masalah Penting : Jakarta : Ghalia.

Todaro,Michael P.,and Smith Stepen,C.(1999) Pembangunan Ekonomi di dunia Ketiga, 1 dan 2 ; Jakarta : Erlangga.

Website Badan Penanaman Modal Prov.Jatim ; http://bpmjatim.com.id 